\title{
THE CONCEPT OF ISLAMIC PARENTING IN THE ERA OF ISLAMIC MODERATION: AN ANALYSIS OF HURLOCK'S PARENTING THEORY
}

\author{
Vivi Yulia Nora* \\ 1 State Islamic Institut of Bukittinggi (LAIN) Bukittinggi, Indonesia, e-mail: viviyulianora@gmail.com \\ *Corresponding Author

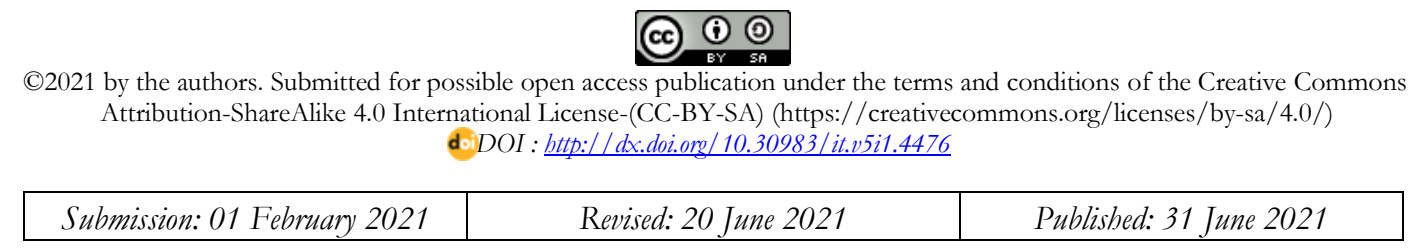

\begin{abstract}
This article describes the parenting proposed by Hurlock and its relevance to parenting in Islam in the face of Islamic moderation demands. This research is comparative research with data analysis techniques using content analysis and descriptive analysis. This research concludes that there are two Hurlock's parenting patterns related to Islamic parenting, namely authoritarian and democratic parenting. In Islamic Parenting, parents parenting is not authoritarian and not too permissive towards children; this is in line with the concept of Wasatiyyah in Islam, which means in the middle. This parenting is one of the examples of Noah AS., Ibrabim AS., and Luqman as told int the Qur'an, and the example og prophet Mubammad $S A W$., in the Sunnah. To face the moderation of Islam, parents can apply these two parenting styles to their children. Through moderate but still Islamic parenting, it is hoped that it can make a generation that can become part of the "ummatan wasatan", namely a generation that has good, fair, and not extreme characters, and is independent, not taking sides except for what is right according to the teachings of the Shari'a.
\end{abstract}

Keyword: Parenting, Hurlock, Islamic Parenting, Moderation of Islam

\begin{abstract}
Abstrak
Artikel ini memaparkan tentang pola asuh yang dikemukakan oleh Hurlock dan relevansinya dengan parenting dalam Islam dalam menghadapi tuntutan moderasi Islam. Penelitian ini adalah penelitian komparatif dengan teknik analisis data menggunakan analisis konten dan analisis deskriptif. Adapun kesimpulan dari peneltian ini adalah bahwa terdapat dua pola asub Hurlock yang memiliki keterkaitan dengan parenting Islami, yaitu pola asuh otoriter dan demokratis. Dalam Pola Asub Islami orang tua dalam pengasuban Anak tidak otoriter dan tidak terlalu permisif terhadap anak, hal imi senada dengan konsep Wasatiyyah dalam Islam yang artinya ditengah Pola asub tersebut merupakan salah satu keteladanan Nabi Nub As., Nabi Ibrabim AS., dan Luqman yang diceritakan dalam al-Qur'an, serta keteladanan Nabi Muhammad dalam Sunnah. Untuk menghadapi moderasi Islam dua pola asub tersebut dapat diterapkan oleh orang tua terhadap anaknya. Melalui pola asub moderat namun tetap islami diharapkan dapat menjadikan generasi yang mampu menjadi bagian dari "ummatan wasațan", yaitu generasi yang memiliki karakter baik, adil, dan tidak ekstrem, serta bersifat independen, tidak berpibak kecuali kepada hal yang benar menurut ajaran syariat.
\end{abstract}

Kata Kunci: Pola asuh, Hurlock, Parenting Islami, Moderasi Islam

\section{Background}

Every individual in Islam must protect their family from bad things that plunge him. This obligation can be understood from the word of Allah SWT., in Surah al-Tahrīm verse 6. In this verse, Allah SWT commands believers to protect themselves and their families from the fire of the all-powerful hell.

In general, the parents should look after the family. The care in question is sometimes related to the child's physical, psychological, and spiritual. It is because parents are the first place to learn for their children.

Success in caring for children cannot be separated from the parenting applied by parents to their children. The correct 
parenting pattern determines the child's character, including how he faces the life of the world and the hereafter. Rasulullah SAW said that children are born in a state of fitrah (pure) ${ }^{1}$, their parents will demand how they will be. Good or bad children depend on how their parents direct them ${ }^{2}$.

Children have not been able to think carefully about what they are experiencing and facing. Without the role of parents, children will fall into negative things in their environment. Therefore, it takes good competence for parents to produce a good generation as well. Parental control over children's development will determine whether a more competent and well-

1 Sayyid Qutub in his book of commentaries suggests that there is a connection between the nature of the human soul and religious character. These two things were created by God in humans as the initial foundation for humans to receive wisdom, change themselves from bad things to better ones, and treat sick souls. see Sayyid Qutub, Tafsir fì Zilāl al-Qur'an, Juz 5, (Kairo: Dār alSyurūq, 2003), p. 2726.

2 There are several editorials in the hadith books regarding the words of the Prophet Muhammad, regarding this matter, including in the aḥīh al-Bukhārī Kitab al-Janāiz Bab Kalām al-Mayti 'alā al-Janāzah with the following editorial:

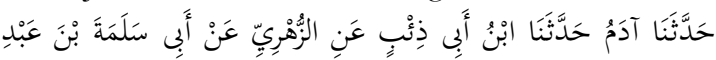

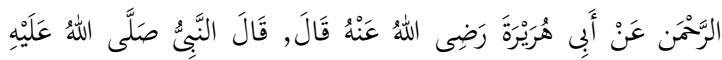

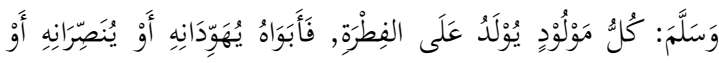

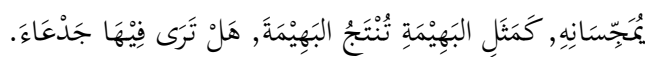

Meaning: "Had told us Adam, had told us Ibn Ab i'bin from al-Zuhrī from Abī Salamah ibn 'Abd alRaḥmān from Ab Hurairah ra., said, The Prophet SAW., said: Every child is born in a state of fitrah (holy), until (then) his parents make him (a) Jew, Christian, or Magian, just as cattle are born by their mothers, have (you) ever seen their children have their ears cut off." Look Abū Abdullah Muhammad ibn Ismā’îl al-Bukhārī, al-Jamì’ al-Ṣaḥihh, Juz 1, (Mesir: Matba'ah al-Salafiyyah, $1403 \mathrm{H})$, p. 424. Other editorials can also be seen in Imām Abī al-Husaini Muslim ibn al-Hajajāj al-Qusyairī al-Naisābūrī, Saḥ̂h Muslim, Juz 4, (ttp: Dār Iḥyā’ al-Kutub al-'Arabī, tt), h. 2047. Lihat juga Imām al-Hāfiz Muhammad ibn 'Īsā ibn Saurah al-Tirmiżī, Sunan al-Tirmiž̀i, (Riyaụ: Maktabah al-Ma’āirif, 1417 H), p. 483. adjusted child will be produced in the future.

Islam has long taught how to properly parenting children. Some parenting patterns can be imitated from Prophet Noah AS, Prophet Ibrahim AS, and Luqman. The average parenting applied is through direct interaction (dialogue) with soft words. It can be seen from the choice of the word "yā bunayya" (O my son) when the prophets and Luqman spoke and or advised their children. ${ }^{3}$

Today, various theories have emerged from experts regarding child parenting, including Elizabeth B. Hurlock's view. Hurlock said that parenting is divided into three types, namely authoritarian, permissive, and democratic parenting. ${ }^{4}$

It proves that parenting is essential to discuss and pay attention to. Moreover, nowadays, life problems are increasingly complex, while the times demand Islamic moderation, namely a condition where individuals must be in an independent position, not taking sides except for what is proper. Therefore it is necessary to study how modern parenting is relevant to the parenting pattern that has been described in the Qur'an and Sunnah.

The author raises Hurlock's theory in this paper because the parenting style he describes, in theory, is a parenting pattern that parents widely apply in everyday life,

3 This can be seen in the letter Hūd verse 42 when the Prophet Noah AS, asked his son to come with him to board the ship. Then, a similar call was also made by Prophet Ibrahim to Prophet Isma'il when he asked for an opinion in Surah alȘaffāt verse 102. In Luqman's letter it is also counted three times how Luqman called his son when he gave advice, namely in verse 13, 16 and 17 . See Muhammad Fuād 'Abd al-Bāqī, Mu'jam alMufahras li al-alfäz al-Qur'ān al-Karim, (Mesir: Maṭba'ah Dār al-Kutub al-Mișriyyah, 1364 H), p. 138.

4 Elizabeth B. Hurlock, Child Development, Terj. Meitasari Tjandrasa, Jilid 2, Ed.6, Jakarta: Erlangga, 2002), p. 93. 
and the theory seems to have some similarities with the parenting pattern described in the Qur'an and Sunnah. So this will make it easier for the author to compare these theories.

This research is comparative research (comparative research), a study to compare the similarities and differences between two or more facts and characteristics of certain objects based on a certain framework of thought.

The method used in this research is by tracing the literature related to parenting according to Hurlock, such as his work entitled Child Development and Developmental Psychology and parenting patterns contained in the Qur'an and Sunnah.

Content analysis and descriptive analysis were carried out based on the literature obtained in data analysis techniques. Later, the two were compared by looking for similarities and differences between the parenting styles proposed by Hurlock and those described in the Qur'an and Sunnah. At the end, the writer will conclude.

This paper intends to explain about how the parenting style, according to Hurlock, how the Islamic parenting pattern, namely the parenting pattern described in the Qur'an and Sunnah to find the relevance between the two then so that the character of the child is ready with Islamic moderation.

Understanding Islamic Parenting and Moderation

Understanding Parenting

Parenting consists of two words, "pattern" and "parenting". The word "pattern" in the Big Indonesian Dictionary means "system, way of working", 5 while the

5 Tim Penyusun Kamus Pusat Bahasa, Kamus Bahasa Indonesia, (Jakarta: Pusat Bahasa, 2008), p. 1197. word "care for" means "to take care of (care for and educate) small children". ${ }^{6}$ If put together, then parenting can be interpreted as a system or way of maintaining, caring for and educating children.

In the book Quantum Parenting, it is stated that parenting is a process of childrearing using methods and/or techniques that are centered on the affection and sincerity of love from parents. ${ }^{7}$

According to Casmini as quoted by Listia, parenting is everything related to how parents treat, educate, guide and discipline their children, and also includes how parents protect or supervise children in the process of becoming adults in order to conform to the norms that apply in society. ${ }^{8}$

Meanwhile, according to Hurlock, parenting can be interpreted with discipline. Discipline tells about how to provide education for children so that they know the good and the bad and at the end, they are encouraged to behave according to the standard of behavior of society in general. ${ }^{9}$

Based on the above definition, it can be concluded that parenting is a way for parents to discipline their children in the form of supervision and care, so that they have good character and can be accepted by society in general.

\section{Understanding Islamic Moderation}

Islamic moderation is a concept that refers to the verse of the Qur'an, namely in Surah al-Baqarah verse 143. There is the word "ummatan wasațan" in that verse, which means "middle people". Ibn Kasīir in his commentary explains that the meaning of

\footnotetext{
6 Tim Penyusun Kamus Pusat Bahasa, Kamus Bahasa..., p. 98.

7 Mohammad Takdir Ilahi, Quantum Parenting, (Jogjakarta: Ar-Ruzz Media, 2013), p. 133.

${ }^{8}$ Listia Fitriyani, Peran Pola Asub Orang Tua dalam Mengembangkan Kecerdasan emosi Anak, Jurnal Lentera, Vol. XVIII No. 1, Juni 2015, p. 101-102.

${ }^{9}$ Elizabeth B. Hurlock, Child Development, p. 59.
} 
the word "ummatan wasatan" is the best choice. Allah mentions that Muslims are the wasaan ummah because they are given specialties through the perfect shari'ah, the straightest path, and the clearest understanding. In addition, based on a hadith narrated by Bukhārī, Tirmiż̄i, Nasā'i, and Ibn Majah that "al-wasaț" means fair. ${ }^{10}$

In Arabic, the word Islamic moderation is called al-Wasațaniyyah alIslamiyyah, while in English it is called Islamic Moderation. Understanding the meaning of Islamic moderation can be seen from the words "moderation" and "Islam". Moderation is the reduction of violence or the avoidance of extremes ${ }^{11}$, while Islam in terminology can be interpreted as a revealed religion that adheres to monotheism or the oneness of God revealed by Allah SWT to the Prophet Muhammad SAW, and applies to all human beings covering all aspects of life. $^{12}$

Islamic moderation is a view or attitude that tries to put oneself in a middle position when faced with two or even more contradictory or excessive things and attitudes, so that two or many things do not dominate in one's thoughts or attitudes. ${ }^{13}$

The author in this case has a slight difference regarding the meaning of Islamic moderation. Islamic moderation in practice is an independent attitude, which is a condition that positions a person in something that is not excessive, does not

10 Abī Fidāi Ismā’̄il ibn 'Umar ibn Kasīir alDimasyqī,Tafsìr al-Qur'an al-'Ażim, Juz 1, (Riyaḍ: tp, 1997), p. 454-455.

11 Tim Penyusun Kamus Pusat Bahasa, Kamus Bahasa..., p. 1035.

12 Misbahuddin Jamal, Konsep al-Islam dalam al-Qur'an, Jurnal al-Ulum, Vol. 11 N0. 2, Desember 2011, p. 287.

13 Abd Rauf Muhammad Amin, Prinsip dan Fenomena Moderasi Islam dalam Tradisi Hukum Islam, Jurnal al-Qalam, Vol. 20 Ed. Khusus, Desember 2014, p. 24-25. lean towards one thing unless it is the right thing according to sharia.

There are two characteristics of Islamic moderation: the right to freedom, which is always balanced with obligations. Second, there is a balance between the life of the world and the hereafter. It also talks about the material and spiritual affairs. ${ }^{14}$

\section{Hurlock's Perspective}

Parenting Patterns

Hurlock's full name is Elizabeth Bergner Hurlock. He was born in 1898 and died in 1988 in Georgia, America. Not found a complete biography of Hurlock, but during his life he has authored several books, including Personality Development, Child Growth and Development, Adolescent Development, and so on.

Talking about parenting, Hurlock has three forms of parenting for their children, namely authoritarian, permissive, and democratic.

\section{Authoritarian Parenting}

Parenting in this form is parenting in which children are forced to follow the behavior or words of their parents. Children are not given the freedom to act outside the example of their parents. In this parenting pattern, the action is usually accompanied by punishments if the child is considered violating the rule.

On the one hand, authoritarian parenting positively influences children, including making children obedient, disciplined, and responsible for their mistakes. However, on the other hand, this kind of parenting makes children passive, afraid of being wrong, and not creative. It

14 An Ras Try Astuti, dkk., Tantangan Parenting dalam Mewnjudkan Moderasi Islam Anak, Jurnal al-Maiyyah, Vol.11 No.2, Juli-Desember 2018, p. 306 
then makes the child shy, aloof and immature in character. ${ }^{15}$

The characteristics of authoritarian parenting:

1. Children are required to obey the rules made by their parents and they must not argue with them

2. Parents tend to give physical punishment to their children.

3. Parents tend to give orders and require their children to carry out orders without any compromise.

4. Parents are rejecting and emotional

5. Parents are stiff in attitude.

Authoritarian parenting causes children to become timid, introverted, quiet, do not like to take initiative, likes to oppose, likes to violate norms, has a weak personality, is anxious and likes to withdraw, is not confident in trying new things and is shy. Authoritarian parenting requires the child to say the word "yes" without listening to the opinion of the child. ${ }^{16}$

\section{Permissive Parenting}

Permissive parenting is a parenting style that frees children to do or respond to things according to their wishes. Children are not required to ask their parents for consideration every time they make a decision. There are no binding rules or punishments in this permissive parenting style. So that permissive parenting is often referred to as a form of neglect parenting. ${ }^{17}$

The characteristics of permissive parenting:

15 Abu Ahmadi, Sosiologi Pendidikan, Jakarta: Rineka Cipta, 1991), p. 112.

${ }^{16}$ Elia Daryati, Anna Farida, Parenting with heart (Bandung: Kaifa,2014) cet. 11, p. 56

17 Rabiatul Adawiyah, Pola Asub Orang Tua dan Implikasinya Tehadap Pendidikan Anak (Studi pada Masyarakat Dayak di Kecamatan Halong Kabupaten Balangan), Jurnal Pendidikan Kewarganegaraan, Vol. 7 No. 1, Mei 2017, p. 35.
1. Parents are less likely to reprimand their children when they are in trouble or in danger. Parents also give very little guidance and direction to their children.

2. Parents are more likely to only pay attention to the material needs of their children

3. Parents give very broad freedom to children and encourage children to regulate themselves, without any direction from the rules and norms of parents.

The application of permissive parenting can make children less disciplined with the social rules around them. Permissive parenting will result in children being impulsive, disobedient, aggressive, spoiled, wanting to win on their own, socially immature. and creative.

\section{Democratic Parenting}

According to Hurlock, democratic parenting can be seen from how discipline is instilled in children. This parenting style emphasizes explanation, discussion, and reasoning from parents to their children. This pattern is expected to make children understand why something is prohibited or allowed. ${ }^{18}$

The characteristics of democratic parenting:

1. Parents give freedom and responsibility to their children to choose and take actions that they think are good

2. Have a responsive attitude to the child's abilities

3. Encouraging children to express their freedom of action and opinion

4. Giving explanations to children about the consequences of bad

18 Elizabeth B. Hurlock, Psikologi Perkembangan, Terj. Istiwidayanti dan Soedjarwo, (Jakarta: Erlangga, 1999), p. 93-94. 
deeds and the consequences of good deeds

5. Give rewards for every success obtained by the child.

Democratic pattern requires more energy for parents, because parents must always give space for children to express themselves. Parents' lack of patience in waiting for their children's initiatives will cause parents to become authoritarian parents ${ }^{19}$.

Based on this, it can be understood that, in essence, parents with democratic parenting prioritize the needs of their children. However, the priority concept applied is carried out rationally and realistically. It makes the children do not feel burdened between doing what parents expect or what is following the child's choice because everything is discussed openly and warmly.

\section{The Concept of Parenting In Islam}

In the dictionary of psychological terms, the concept of parenting is all actions that adults do to their children in terms of caring for, protecting, teaching, disciplining, and providing guidance to their children. Thus, the concept of parenting in Indonesian can be interpreted as child care. Researchers believe that parenting has an impact on children such as behavioral problems, adjustment, competence and internalization of values. ${ }^{20}$

All parents want their children to be a generation with noble character and intelligence, but this cannot be achieved if parents do not have good parenting knowledge. Islamic parenting is a parenting model that parents can apply so that their children have good morals because Islamic parenting teaches children to be democratic.

\footnotetext{
${ }^{19}$ Elia Daryati, Anna Farida, Parenting With Heart, (Bandung: Kaifa, 2014) Cet. 11, p. 14

${ }^{20}$ An Ras Tri Astuti, dkk., ibid.
}

Children are not forced to do the things they want to do.

The achievement of good expectations of parents for the child cannot be separated from the consistency of parents in applying several principles in parenting, including al-'science of qabla al'amal wa al-qaul and tarahum. ${ }^{21}$

Al-ilmu qabla al-'amal wa al-qaul means that parents first know and understand parenting science before applying it to children. This is expected so that parents can provide appropriate parenting and follow children's needs, and of course, it does not conflict with Islamic values. The purpose of the principle of tarahum is to love. There are many theories about parenting, but the most important thing is its application with love, one example is looking at the child when he tells a story or when he advises him, praying for goodness for him and so on.

Apart from being consistent with the two principles mentioned above, good parenting should also be adapted to the child's condition. Al-Jauhari said that several things must be considered regarding this, namely: ${ }^{22}$

1. Provide care following the development, growth and ability of children. When the parenting provided is not following this, the child will certainly find it difficult to understand and accept it so that it will interfere with the development of reason and affect confidence in himself.

2. Convey to the child the parenting concept that is applied so that he

21 Ahmad Naqieb Alinaksi dan Endah Puspita Sari, Dinamika Kompetensi Pengasuban Islami, Jurnal Psikologika, Vol.20 No.2, 2015, p. 218.

22 Al-Jauhari Mahmud Abdullah, dkk., Membangun Keluarga Qur'ani: Panduan Untuk Muslimah, (Jakarta: Amzah, 2005), p. 230 
understands and is not confused by the rules made by his parents

3. Use a critical approach to the child in conveying something, namely by explaining the advantages and disadvantages of the thing to be conveyed, then give space for the child to judge for himself the best version according to him.

4. Apply to children good and straight rules so that their thoughts are clean from the beginning of their development.

5. Train and accompany children to apply the rules made and solve the problems they face

6. Train children to seek the truth with an objective approach, so that they become individuals who are consistent in upholding the straight principles of life.

7. Keep children away from anxiety, psychological conflicts, mental disorders and other problems so that they grow and develop in a healthy manner, both physically, logically and psychologically.

Prophet Noah AS., always treated his son well, this can be seen from how he advised his son, Qan'ān, illustrated in Surah Hūd verses 42-43. The verse explains that the Prophet Noah AS., still calls his son with a good call, even though his son has rebelled. In addition, it can also be seen that Prophet Noah AS, in terms of belief, was very authoritarian and firm towards his son, ordering his son to follow what he believed in, namely to believe in Allah SWT. It is illustrated in the next verse when the Prophet Noah AS, said that no one would be able to help except Allah, the Most Merciful.
The strict parenting pattern is also illustrated by Luqman's advice to his children in Surah Luqman verse 13 and verse 17. In these two verses, Luqman is very firm in advising his child in terms of faith in Allah SWT. He said that associating partners with Allah is enormous injustice. In addition, he also emphasized to his son never to neglect prayer as a form of worship to Rabb al-'Alamin. To call for goodness to all humankind and be patient for all the bad things that happen to him.

Luqman AS., in verses 14-15, also ordered his children always to be devoted and do good to their parents. A child must obey his parents except in the case of error and disobedience.

Based on this, it can be understood that Islam is very strict on matters relating to aqidah and obligatory worship that the Shari'a has determined. Prophet Muhammad SAW, even once said to punish children who do not carry out the obligation of prayer (worship), as narrated by Abū Dawud below:

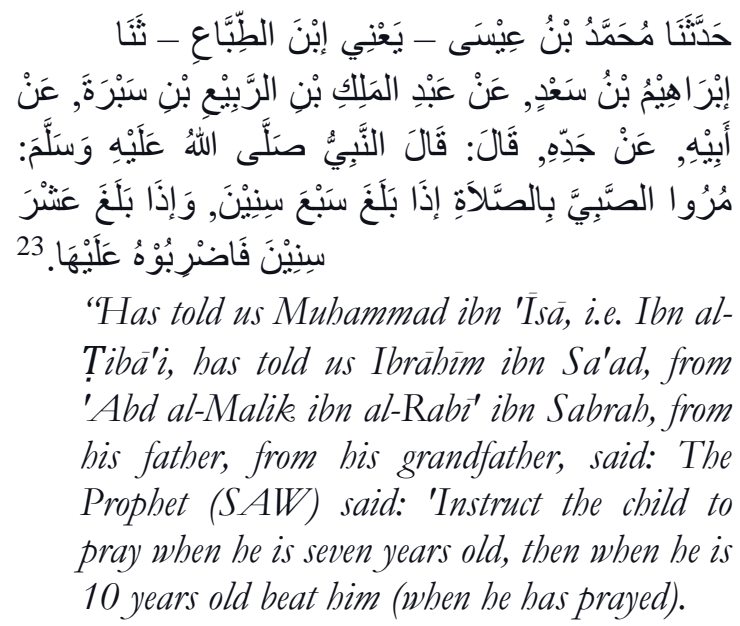

Furthermore, Prophet Ibrahim AS, gave an example that parents and children need sharing in solving a problem. This can be seen from the discussion of Prophet

23 Abū Dāwud Sulaimān ibn al-Asy'aṣ alSajastānī, Sunan Abì Dāwud, (Riyāẹ: Maktabah alMa’ārif, 1424 H), hp 91. 
Ibrahim AS, in Surah al-Ṣaffāt verse 102 when he dreamed of slaughtering his son, Prophet Isma'il AS.

The verse explains that Prophet Ibrahim invited to discuss something related to his son. Through discussion, everything looks more pleasant because of the openness.

In addition to the parenting patterns mentioned above, there are several parenting methods in Islam, including showing an example and paying attention to children.

One form of exemplary and caring can be seen from the upbringing of the Prophet Noah AS. He still treats his son well even though his son refuses to follow the teachings of monotheism. It is a form of exemplary. While the form of attention is when he is still praying and asking forgiveness from Allah SW'T for his child's disbelief. As the word of Allah SWT, in the following Surah Hūd verse 45:

"And Noab cried out to his Lord, saying: 'My Lord, indeed my son is part of my family, and indeed Your promise is true, indeed You are the most just judge."

Islamic parenting certainly has some differences from general parenting unrelated to Islamic values. There are at least two striking differences, namely regarding vision and order in life. ${ }^{24}$

In Islamic parenting, parents have several visions, such as a vision of 5 to 10 years of child growth and development, or until they are adults. The vision of Islamic parenting is about how children are happy and successful in the world and how children will be happy and safe in the hereafter.

As for the differences regarding the order of life, Islamic parenting has a clear order of life and is following the vision of

24 Ahmad Naqieb Alinaksi dan Endah Puspita Sari, ibid. life in the long term. An orderly life that has a long-term vision will ideally be of higher quality because of course it is thought out carefully.

\section{The Relevance of Moderate And Islamic Parenting Patterns Towards Islamic Moderation}

Based on the previous discussion, it is known that there are three forms of moderate parenting proposed by Hurlock, namely authoritarian, permissive or neglectful parenting, and democratic parenting. If it is associated with Islamic parenting, the author considers that there is relevance to several aspects of the parenting style proposed by Hurlock, namely with regard to authoritarian and democratic parenting.

Referring to the example that can be taken from the story of Noah in Surat Hūd, the story of Luqman in Surah Luqman can be seen that both of them are very strict with their children. Prophets Nuh and Luqman both emphasized that their children should not associate partners with Allah. This attitude can be referred to as authority, namely parenting by forcing children to follow what is best in the opinion of their parents, which in this case relates to faith and belief.

Furthermore, parenting in Islam has an element of sharing or deliberation. It is illustrated by how Prophet Ibrahim invited his son to discuss his son's personality. If it is associated with Hurlock's opinion, then the parenting pattern can be equated with the democratic pattern proposed by Hurlock.

As for permissive parenting, it seems that this does not exist in Islam because Muslims were created as the best people who can prevent evil. It is based on the word of Allah in Surah Ali Imran verse 110.

The two parenting styles mentioned above, namely authoritarian and 
democratic, seem appropriate if applied to children facing Islamic moderation as it is known that the moderation of Islam today is very much heard. It could be due to the many extreme thoughts and understandings that often corner some parties who disagree with other parties. This extreme understanding is usually motivated by an individual's poor character.

Instilling good character in children as early as possible can prevent them from thinking and understanding extremes, given that in essence children do have their own character. This can be seen from the verses of the Qur'an which classify children into four groups, namely children as jewelry in the world ${ }^{25}$, child as a test ${ }^{26}$, child as enemy ${ }^{27}$, and the child as the light of the eye or the jewel of the heart ${ }^{28}$.

Through the correct parenting style from parents, there is hope that children will be enough to become jewels and lights of the eyes or jewels of the heart, both for their parents, religion, and the general public. Apart from that, in Surah al-Nisa' verse 9 , it is not permissible to leave weak offspring, both physically and psychologically, even more so spiritually.

Apart from the above, as explained earlier, the Islamic parenting concept and the parenting concept, in general, have different goals. The purpose of parenting in Islam is to reach prosperity in the world and the hereafter, it is only because of Allah SWT. Meanwhile, the concept of parenting in general, according to Elbert, as quoted by Ahmad and Endah, aims to produce children who excel (achievement), children

\footnotetext{
25 Ayat yang menyebutkan tentang hal ini terdapat dalam Surat al-Kahfi ayat 46.

26 Anak sebagai ujian disebutkan dalam firman Allah Surat al-Anfāl ayat 28.

27 Anak sebagai musuh dijelaskan dalam Surat al-Taghabun ayat 14 .

28 Anak sebagai permata hati termaktub dalam firman Allah Surat al-Furqān ayat 74 .
}

who are independent (independence), and children who respect their parents (respect for parents). In addition, it is also mentioned that the purpose of parenting is for children to grow up happy and smart (raise happy and smart children). ${ }^{29}$

\section{Conclusion}

Moderation of Islam is essential, although there are still barriers that cannot be disturbed, namely everything related to aqidah. Although "moderate" has a close understanding of "democracy", but in terms of aqidah everything has been confirmed in the Qur'an and Sunnah so that it cannot be mixed up.

The concept of moderation can also be applied in parenting, where parents are not authoritarian but also not too permissive towards children, this is in line with the Wasatiyyah concept in Islam, which means middle.

In order to deal with Islamic moderation, it is necessary to understand from the beginning, especially from parents to their children, one of which is through parenting and proper and correct parenting principles. The principle in question is related to exemplary, accompanying children in realizing moral values, teaching democratic attitudes, being open, honest, and consistent in carrying out the rules made and mutually agreed upon. In addition, children's authority and trust in their parents also play an important role in the success of parenting. ${ }^{30}$

Islamic parenting can be imitated from the stories in the Qur'an, namely based on how the prophet faced his child,

29 Aubanova, What is your Parenting Goal?, http://parentingforeveryone/goals/, diunggah tahun 2007, diakses tanggal 26 September 2021.

30 Ahmad Yani, dkk., Implementasi Islamic Parenting dalam Membentuk Karakter Anak Usia Dini di RA At-Taqwa Kota Cirebon, Jurnal Awlady, Vol.13 no.1, (2017) 155 
as well as through the Sunnah of the Prophet Muhammad. In addition, there is also a moderate parenting style that is considered quite relevant to Islamic parenting, one of which is Hurlock's authoritarian and democratic parenting.

Through moderate but still Islamic parenting, it is hoped that it can make a generation that is able to become part of the "ummatan wasațan", namely a generation that has good, fair, and not extreme characters, and is independent, not taking sides except for what is right according to the teachings of the Shari'a.

\section{References}

Abdullah, Al-Jauhari Mahmud dkk. Membangun Keluarga Qur'ani: Panduan Untuk Muslimah. 2005. Jakarta: Amzah.

Adawiyah, Rabiatul. Pola Asuh Orang Tua dan Implikasinya Tehadap Pendidikan Anak (Studi pada Masyarakat Dayak di Kecamatan Halong Kabupaten Balangan). Jurnal Pendidikan Kewarganegaraan. Vol. 7 No. 1. Mei 2017.

Ahmadi, Abu. Sosiologi Pendidikan. 1991. Jakarta: Rineka Cipta.

Alinaksi, Ahmad Naqieb dan Endah Puspita Sari. Dinamika Kompetensi Pengasuhan Islami. Jurnal Psikologika. Vol.20 No.2. 2015.

al-Bāqī, Muhammad Fuād 'Abd. Mu’jam alMufahras li al-alfāz al-Qur’ān alKarīm. 1364 H. Mesir: Maṭba'ah Dār al-Kutub al-Mișriyyah.

al-Bukhārī, Abū Abdullah Muhammad ibn Ismā’̄il. al-Jamì al-Ṣaḥịh. Juz 1. 1403 H. Mesir: Mațba'ah al-Salafiyyah.

Amin, Abd Rauf Muhammad. Prinsip dan Fenomena Moderasi Islam dalam Tradisi Hukum Islam. Jurnal alQalam. Vol. 20 Ed. Khusus. Desember 2014.
al-Naisābūrī, Imām Abī al-Ḥusaini Muslim ibn al-Ḥajjāj al-Qusyairī. Șaḥīh Muslim. Juz 4. tt. ttp: Dār Iḥyā’ alKutub al-'Arabī.

al-Dimasyqī', Abī Fidāi Ismā'īl ibn 'Umar ibn Kaśīr. Tafsīr al-Qur’an al-'Aẓim. Juz 1. 1997. Riyad: tp.

An Ras Tri Astuti, dkk. Tantangan Parenting dalam mewujudkan Moderasi Islam Anak. Jurnal AlMaiyyah. Vol.11 No.2, Juli-Desember 2018.

Aubanova. What is your Parenting Goal?. http://parentingforeveryone/goals/.

Diunggah tahun 2007. Diakses tanggal 26 September 2021.

Ayuni, Qurrotu. Pola Asuh Orang Tua dan Metode Pengasuhan dalam Membentuk Kepribadian Anak. Jurnal ThufuLA. Vol. 5 No. 1. Januari-Juni 2017.

Elia Daryati, Anna Farida, Parenting with herath, cet. II 2014 Bandung: Kaifa

Fitriyani, Listia. Peran Pola Asuh Orang Tua dalam Mengembangkan Kecerdasan emosi Anak. Jurnal Lentera. Vol. XVIII No. 1. Juni 2015.

Hasanah dan Nur Aini Zaida. Pola Asuh Anak Usia Dini dalam Islam. Jurnal alAqidah. Vol. III No. 1. Januari-Juni 2020.

Hurlock, Elizabeth B. Child Development. Terj. Meitasari Tjandrasa. Jilid 2. Ed.6. 2002. Jakarta: Erlangga.

------, Psikologi Perkembangan. Terj. Istiwidayanti dan Soedjarwo. 1999. Jakarta: Erlangga.

Ilahi, Mohammad Takdir. Quantum Parenting. 2013. Jogjakarta: Ar-Ruzz Media.

Jamal, Misbahuddin. Konsep al-Islam dalam al-Qur'an. Jurnal al-Ulum. Vol. 11 N0. 2. Desember 2011.

Jannah, Miftahul. Pola Pengasuhan Orang Tua dan Moral Remaja dalam Islam. 
Jurnal Ilmiah Edukasi. Vol. 1 No. 1. Juni 2015.

Qutub, Sayyid. Tafsir fị Zilāl al-Qur'an. Juz 5. 2003. Kairo: Dār al-Syurūq.

al-Sajastān̄i, Abū Dāwud Sulaimān ibn alAsy'aș. Sunan Abī Dāwud. 1424 H. Riyāḍ: Maktabah al-Ma'ārif.

Tim Penyusun Kamus Pusat Bahasa. Kamus Bahasa Indonesia. 2008. Jakarta: Pusat Bahasa.
al-Tirmiżī, Imām al-Ḥāfiẓ Muhammad ibn '̄̄sā ibn Saurah. Sunan al-Tirmiżī. 1417 H. Riyaḍ: Maktabah al-Ma'ārif.

Yani, Ahmad dkk. Implementasi Islamic Parenting dalam Membentuk Karakter Anak Usia Dini di RA AtTaqwa Kota Cirebon. Jurnal Awlady. Vol.13 No.1. 2017. 